likely that the pinks used in the two sets of experiments were genetically different, and that one is more closely linked with bandless while the other shows appreciable recombination. The alternative that the same genes may show variable linkage in different strains is, however, not excluded.

$$
\begin{aligned}
& \text { Galton Laboratory, } \\
& \text { University College, } \\
& \text { London, W.C.1. } \\
& \text { May 9. } \\
& { }^{1} \text { Diver, C., Proc. Sixth International Cong. Gen., 2, } 236 ; 1933 .
\end{aligned}
$$

\section{Crystalline Estrus-producing Hormone from Horse (Stallion) Urine}

Prof. B. ZoNDEK ${ }^{1}$ has published results on the high quantities of œstrus-producing hormone present in horse (stallion) urine. By application of the method employed in this Institute for the preparation of crystalline œstrogenic hormones from the urine of pregnant mares, a few milligrams of crystals of high œstrogenic activity were obtained from 5 litres of horse urine.

They were rhomboid plates, melting after re. crystallisation from alcohol at $254^{\circ}-255^{\circ}$, and when mixed with a sample of $\alpha$-folliculin ( $\alpha$-œstrone) melting at $257^{\circ}-259^{\circ}$, the melting point of $254^{\circ}-256^{\circ}$ was obtained.

As predicted by Zondek by the comparison of the physiological properties, the isolated substance seems to be identical with the hormone of the urine of pregnant women. Greater quantities of horse urine are now being worked in order to identify the hormone with certainty.

Instituto Bacteriológico D.N.H.,

Venancio Deulofeu.

$$
\text { J. Ferrari. }
$$

Velez Sarfield 563,

Buenos Aires, Argentine. April 30.

${ }^{1}$ Nature, 133, 209, Feb. $10 ; 494$, March 31, 1934.

\section{Crocodiles or Alligators?}

THere has recently been published the part of "Das Tierreich" dealing with Reptilia Loricata, and since this great work is bound to be widely used by zoologists in the naming of species, it becomes of considerable importance in the stabilising of zoological nomenclature. One therefore examines with more than usual interest the generic and specific names adopted by Dr. Franz Werner for crocodiles and alligators. Again the strict application of the laws of priority in nomenclature gives rise to some confusion. The generic name Crocodilus, as applied to Old World crocodiles (Crocodilidæ) by Cuvier in 1807 , is replaced by Champse of Merrem (1820), the reason being that in 1768 Laurenti had used the name Crocodylus with another significance.

Following Laurenti's usage the name Crocodylus is accordingly applied to two South American species of alligators, so that, in the first place, confusion arises between the old-established distinctions between crocodiles and alligators, and, in the second place, the family name Crocodilidæ (although still retained) loses its significance, since it no longer includes the genus Crocodilus.
More unfortunate still, the specific name of the tropical South American alligator, widely known as trigonatus, has, following Laurenti, become Crocodylus niloticus, so obvious a misnomer that its meaning can only lead to confusion.

My impression is that the laws of priority provide against the perpetuation of obvious mistakes; in any case, if Laurenti, more than a century and a half ago, made the blunder of naming a South American form under the impression that he was naming a specimen from the Nile, there seems to be no good reason why the blunder should be stabilised in a scientific system. It is on a par with, though more confusing than, the retention of the name Certhia familiaris brittanica for the British treecreeper, because Ridgway forgot for a moment how to spell Britain.

"Sine systemate chaos" is the motto printed on the cover of "Das Tierreich"; but confusion may arise under the cloak of systematics.

University of Aberdeen.

James Ritchie. May 8.

\section{Air-Pockets in Shore Sands and Winter Packing of the Sea-Bottom}

WhILST crossing the Lancaster sands last summer from the village of Flookborough, my attention was attracted by a succession of curious sounds all around me, resembling either profound sighs or the strong flat expirations made through pursed lips by a sleeping person. These sounds were first heard in daylight; but they may have been heard at night in the past by others and given rise to tales of legendary monsters. On searching for the cause I was at once shown it by my companion, Mr. Thomas Wilson; the sounds were due to the escape of air from small pockets below the surface of the wet sand, and could be produced by perforating with one's finger the drying and slightly elevated areas of sand overlying the pockets. The vibration produced in the ground by a pedestrian or a passing cockle-cart appears to increase the air pressure sufficiently to blow off the sandy caps of the pockets.

It occurred to me that the holes and cavities formed in the sand might be of interest to geologists, since similar ones might have become 'fossilised' in past ages and remain to perplex the palæontologist.

These air-pockets have been observed near highwater mark when crossing the sands soon after the recession of the tide; the following explanation is suggested for their formation. At this level the sand dries and drains to a great extent in summer, and especially during the neap tide period. When the spring tide floods set in, water flows very rapidly over the area of dry sand, imprisoning air below the wetted surface. During high and the following ebb tide water gradually percolates below the surface into the underlying sand, driving the imprisoned air into the looser aggregations of sand where it collects and forms a pocket, which may be 'blown' by a gradual accumulation of the encircling water pressure or by a sudden increase due to vibration of the ground.

These miniature air-voleanoes were noticed frequently during the summer, but not during monthly visits in the winter. In April this year they have again appeared. This apparent periodicity is interest. ing in connexion with the prevailing view held by British inshore fishermen that the sea-bottom on the fishing grounds becomes hard or 'closes up' in winter 